\title{
Assessing the perceived limitations of Reflexive Groups for supporting clergy in the Church of England
}

\author{
Peter Madsen Gubi \\ Faculty of Social Sciences, University of Chester, UK.
}

\begin{abstract}
For this research, eight Church of England Bishops' Advisors for Pastoral Care and Counselling were interviewed to ascertain the limitations of Reflexive Groups (RGs). The data were analysed using a thematic analysis. One superordinate theme emerged: Hindrances, along with 10 subordinate themes. An online survey was then sent to RG participants $(n=64)$, to see if their experiences matched those limitations identified by the Bishops' Advisors. The data reveal that RGs are perceived as limited by the inability of clergy to commit to the time; it was scary for participants to be vulnerable with others; sometimes the needs of some participants were too big and could sabotage the group; dual relationships could cause complexity and hinder sharing; prayer; being sent by a Bishop or Archdeacon; the open agenda and style of facilitation does not suit some people; and sometimes there are struggles with expectations.
\end{abstract}

\section{KEYWORDS}

Clergy; support; reflexive; groups; limitations; hindrances

\section{Introduction}

Reflexive Groups (RGs) ${ }^{1}$ are increasingly being utilised and promoted within the Church of England (CofE) (Gubi, 2016a). They create communities of practice for intentional reflection on participants' ministries (Braudaway-Bauman, 2012). These groups give opportunity for openness and honesty before others, and members are required to work towards finding a way to both hold vulnerability and affirm the confidence and authority of the other. They provide a chance for participants to tell their story, to give and receive support and encouragement in the situation in which each incumbent finds him/ herself, and that can be taken back into the life and ministry of each member. However, they do not suit everyone (Miles \& Proeschold-Bell, 2013). Recent small-scale research (e.g. Barrett, 2010; Gubi, 2016b; Gubi \& Korris, 2015; Travis, 2008) has established

\footnotetext{
${ }^{1}$ An RG is defined as a non-directive, closed group that aims to offer opportunities for reflection on interactions and processes in which reflexivity can take place at a psychological, relational and spiritual level (Gubi, 2011, p. 50). RGs are sometimes referred to as Reflective Practice Groups (Barrett, 2010; Gubi \& Korris, 2015), Balint-style groups (Travis, 2008), or Clergy Peer Support Groups (Francis, Robbins, \& Wulff, 2013).
} 
the effectiveness of RGs in supporting clergy in the CofE. Gubi's (2016b) research highlights their value as: offering support, enabling clergy to feel less isolated, enabling clergy to gain an insight into the way that they think and into the impact of their way of being on others, enabling clergy to respect difference better and to gain a better sense of selfcare, enabling clergy to engage in a better quality of pastoral encounter with others and to interact better with others in their ministry, enabling clergy to grow as human beings, enabling trust and vulnerability to be experienced safely, and enabling clergy to negotiate boundaries better. However, Miles and Proeschold-Bell (2013) state that such groups are not beneficial for everyone, and evidence from the use of RGs within other professions (e.g., personal development groups in counsellor training) suggests that such groups have their limitations. Williams and Irving (1996) suggest that they only sometimes lead to positive outcomes. They can sometimes be destructive (Lieberman, 1981) and dysfunctional (Lennie, 2007). Benson (1987) observes the "negatives" of RGs as: feeling excluded or scapegoated; suffering the insensitivities, righteous, relevant or inappropriate anger and clumsiness of others; feeling unsafe and uncontained, over-dependent on or hostile to peers or group leaders; feeling bored, frustrated, impotent or critical of self and /or others - all of which can occur for group participants at any time. Moon (2004) states that not all people find reflexivity easy, and Robson and Robson (2009) argue that such groups do not always feel "safe". Gubi and Korris' (2015) participants identified other participants sometimes giving answers and sometimes not listening as a limitation. This small-scale research seeks to discover how those who facilitate, and take part in, RGs perceive their limitations and hindrances.

\section{Methodology}

The research question that focussed this research was, "do Reflexive Groups have a beneficial place in clergy training, and in supporting clergy, towards enabling a more effective ministry?" The aim was to discover if, and how, RGs support clergy (see Gubi, 2016b for the data on support) -and what might limit their effectiveness (the focus of this article). Ethical approval was gained through the University of Winchester as part of a larger doctoral research project (Gubi, 2016a). The research was conducted in two stages using a mixed methods approach. In Stage One, 42 Bishops' Advisors, identified through the Anglican Association of Advisors in Pastoral Care and Counselling (2015) website, were emailed to ascertain how many of them facilitated RGs, or knew of such groups in their dioceses, and to ask if they could be interviewed if they did. These Bishops' Advisors have responsibility for advising on the provision of mental health care and wellbeing for the clergy in their dioceses. Eight Bishops' Advisors (response rate of $19 \%$ ) responded to indicate that they facilitate (or have facilitated) RGs in their dioceses. They were sent a participant information sheet explaining the details of the research. Semi-structured interviews were setup with the eight respondents. These were digitally audio-recorded and transcribed, and based on the following questions:

- Can you tell me something about the reflexive-type group(s) that you facilitate, or that run in your diocese?

- What might limit or hinder the group(s)? 
The transcripts were member-checked for accuracy, and participants were invited to add to, or amend, the data if necessary. Signed informed consent was gained. The data were analysed using a thematic analysis (Braun, Clarke, \& Rance, 2015). Data attributed to Bishops' Advisors are coded with "BA" and a number (e.g. BA2) to protect anonymity. In Stage Two, an online survey, using the research instrument "Bristol Online Survey", was sent to 64 RG participants, identified by the Bishops' Advisors of three dioceses, with the permission of each diocese. The online survey was sent by blind-copied email from each diocesan office (to preserve the anonymity of the participants, as the diocesan offices already knew who the participants were). The questions in the online survey were based on the data from the Bishops' Advisors' interviews, and asked participants to agree or disagree with the following statements:

I have found that my involvement with my RG has been held back by:

- My difficulty in committing the time to attend regularly

- My difficulty in sharing openly with others

- My difficulty in making time to prioritise attendance

- Others in the group

- The manner of facilitation

- The structured nature of the sessions

- The unstructured nature of the sessions

- The cost

- Feeling unsafe

The purpose of the statements was to discover if the RGs' participants experienced the same limitations as the claims that the Bishops' Advisors were making about the limiting factors of the groups. The details of the research were explained in the pre-survey information. Consent was gained through submission of the survey. The data attributable to each diocese is coded with a $D$ (for diocese) and a number (1, 2 or 3$)$. Within Diocese 1 , the online survey was sent to 29 participants. Participants had two weeks to respond to the survey which took no more than 10 minutes to complete. A reminder email was sent out two days before the closure of the survey. This process was repeated across all three dioceses. Sixteen participants responded in D1 (response rate 55.2\%). Within D2, the survey was sent to eight participants. Seven participants responded (response rate $87.5 \%$ ). In D3, the survey was sent to 27 participants. Fourteen participants responded (response rate $51.8 \%$ ).

\section{Stage one findings}

The data from the Bishops' Advisors are presented using one superordinate theme: Hindrances - with accompanying subordinate themes (see Table 1).

Table 1. Superordinate themes and subordinate themes from the data provided by the bishops' advisors.

\section{Superordinate theme Subordinate theme}

\section{Hindrances}

Time 


\section{Superordinate theme: hindrances}

\section{Subordinate theme 1: time}

All of the BAs felt that the inability of clergy to commit the time was a hindrance factor. BA5 described it in this way:

I think that's why a lot of clergy don't take this up because they - I mean for four years we ran eighteen sessions a year. This year, I've done fourteen sessions just to make it slightly less time intensive as I thought that was an issue for people. For some clergy, even the thought of meeting with their colleagues in that kind of setting, fortnightly, I think just might have felt too much. (BA5)

However, BA3 felt that the Church needed to address this culture of busyness to prioritise time for the development of self-awareness:

Cultural busyness needs to be attacked, because people will say they are too busy, there are too many other things to do, but actually if the church really, really recognises that self-awareness is fundamental to the efficacy of somebody in ministry, then it's a priority, and there should be time. (BA3)

\section{Subordinate theme 2: scary}

Engaging "at depth" is not something that many clergy do and is therefore scary.

I think the cost of opening up to a whole load of people, on that kind of regular basis, is scary for people. (BA5)

\section{Subordinate theme 3: needs are too big}

Sometimes, people left the group because their needs were too much, either for the participant, or the group, to handle. BA5 stated that,

The two people who, over the five years I've been doing the group, have left. It has become clear that their needs were too big for the group. In both cases, they just couldn't somehow use the group. Their needs have just been utterly overwhelming and somehow they couldn't bear the group and the sharing or something. They'd get very frustrated and angry within the 
group where you felt there was a different agenda somehow, something going on. I think unconsciously they might have had unreal expectations of the group actually, so they had to find a way to leave it and, in the end, I think that was probably better that that happened. (BA5)

There is an indication here that RGs may not be for everyone in that psychological or relational damage may exacerbate difficulties for the groups and for the individuals.

\section{Subordinate theme 4: boundaries}

Careful selection of candidates for each group emerged as a theme, as dualboundaries may act as a hindrance to full use of the group experience:

If I felt there was going to be a boundary clash of people who were working too much together already outside, I'd address that and talk about it, but I'd probably not put them in the same group together. (BA5)

BA4 stated that many of her group participants travel some distance to what might be thought of as a "neutral" space, so as to avoid dual-boundaries.

Yes, they generally all travel to it and appreciate being outside their deanery in what is a neutral space for all of them, completely neutral, but it is a space away from their parishes and they specifically wanted that. (BA4)

BA3 had actual experience of not taking into better consideration the mix of the group and their potential dual-boundaries:

Also. the fact that there was only one woman and four men. Three of the men came from the same Deanery which was a very male dominated deanery, so the Deanery-Chapter competitiveness remained. So, the showing of vulnerability was the last thing they wanted to do because they were like that any way, and so the last thing they wanted to do was to be engaged in doing this in public. (BA3)

The consequences of these dual-relationships were:

Any question of looking more deeply at what might be going on, and what internal drivers there might be, or of helping others to explore where they might be, that wasn't what they wanted so they tended to be full of - if we ever got anywhere near something significant, then they would change the subject, get full of anecdotes, problem solved, anything. (BA3)

However, BA3 realised that it was not always possible to be mindful of dual boundaries:

To be put in a group where there is somebody with whom there is antipathy and which could lead to bullying or stifling of your own stuff and it won't be addressed, that would be destructive. So, I do think it's better to have some element of choice in this but often, of course, that's not possible. It would depend on geography as to who you were with. I was facilitating last night, and somebody said, “well, I've got no choice because I can't travel. So, I have to be with people near me, but there is one person that I know I just 
don't want to talk to". So, I'm not sure it's going to be very helpful for her, but it might be. (BA3)

BA6 also took care in the make-up of the groups:

So, we do look at it in terms of are there any obvious personality issues or previous divisions in this cohort? Are there any Churchmanship issues, like we don't want the most "forward in faith" one in with our most radical feminist theological lesbian, for example, ideally. So, we do gerrymander the group...We would try and not have one woman and five men. We would try, perhaps to have two women in the group...So we take some care with that and also whether there are connections with the facilitators, because sometimes there are, you know equally, you want to - you probably know there is too much of a dual relationship. (BA6)

\section{Subordinate theme 5: prayer}

Perhaps unexpectedly (given the clergy context), three of the BAs felt that prayer did not have a place in RGs as it could be a hindrance factor. BA5 stated:

I just don't feel that the purpose of the group is to have prayer and wouldn't feel that that was appropriate. It is interesting that sometimes, at the end of a group, you often find a bit of an unconscious theme running through the group and you find that although ostensibly different, that the two presentations actually have thrown up similar themes and at the end of a group, one of us might make a sort of bit of a gathering comment and if it has been a particularly emotionally charged group, there is often just a little moment of silence which sort of happens naturally and I think that is just a sort of an awareness of something being shared and that is enough, yes...l suspect it puts off some of our more closed evangelical brothers and sisters. I think the open ones would be okay, but I think that you know, they would sort of, "why can't this happen?" sort of thing... It's part of their church culture, but on the other hand, having a different start to a meeting which usually begins and ends in prayer, is also helpful. (BA5)

For BA4, the experience was similar, except that it was the group that requested that they do not pray, because every Church group begins and ends with prayer, and it was important to the group that this group was different:

One of the things we talked about in the beginning was about the group members might come from... theologically their needs are in different places. It's about respecting difference. And we talked about the place of prayer in the group and what they wanted to do about that, and they all said they would not want to start with prayer. Because that sort of becomes an expectation - and every meeting starts with prayer and so it was agreed that, and not only that but then it's "who's turn is it now"? And I just want to come here and I just want to be and I don't want to think, "oh, I've got to do the prayers today". (BA4)

BA8 also highlighted the impact that prayer can have on what has been shared: 
...prayer, and that is a really interesting one because my sense of that is where group members in the early starting off of the group, very occasionally, actually surprisingly, have said, "do we start with prayer or can we end with a prayer?" and of course, I would always say, absolutely, we will now be silent for five minutes. Is it helpful or not, particularly at the end? And a new colleague came to supervision in the early stages and said it was awful because right at the end so-and-so bobbed up and basically disabled the whole of the material of the group by putting it into prayer. So I think, it is really important to be prayerful about the group and I hope they are before they come in, or that we can certainly end with silence and bring those things to God - but actually words are not necessarily the valuable part, and some clergy have found it very difficult. (BA8)

Rather than this being about the use or non-use of prayer, per se, the importance here is in keeping reflective groups "different" from other groups that clergy are used to being in. As prayer marks the beginning and end of much group activity that the clergy engage in, the non-use of prayer is a way of making the space "different". Prayer can also negate (spiritualise away) what has been shared in the group.

\section{Subordinate theme 6: lacking commitment}

BA4 felt that the inability to commit to the process could hinder the benefits of RGs:

Lack of commitment...committing to the time, committing to attending... making the time. Yes, and I think that's one of the reasons may be that they don't because how can I spare the time to come? - especially if they are coming a long way. Geographically, there's an hour to get there and then..., so essentially they are giving up a morning, making the time in the diary for that is certainly a factor and one person recently commented on that, you know, newly first-time incumbent, "I don't think I've time for this. I've had to hit the ground running", and actually somebody said, "this is exactly why you do need to come". And she said, "actually yes, you are right". So, making that time... prioritising..., and that goes back to that thing if selfcare is considered to be something essential then, prioritise it. So that's one thing both committing to time, committing to the process and you've got to feel safe. (BA4)

Commitment, here, is not just about time, but also about a willingness to engage in the process. BA7 also stressed that commitment was important, and that clergy were poor at committing themselves to something that was for themselves:

Clergy are terrible with time, starting and ending. But you know, if they are committed to these groups, it comes before anything else - funerals, or the bishop wanting to see you. So you have that interplay, "Oh, I've got a funeral!" "Well, you did make a commitment." So you are having to educate them afresh about what does it mean to be committed and to put that first...I think that is essential, and you are also helping them to realise 
that this is not a day off. Some of them will go, "oh, it's my day off!" This is work. (BA7)

\section{Subordinate theme 7: being sent}

Being "sent" was identified as a hindering factor:

They were sent and they found it quite difficult to engage with the group process. There was always a funeral or something else that meant that unfortunately they were unable to come, so we never got, only twice I think in a year, the cohorts, all cohort of five and they were very defensive and things were very "out-there" and it was hard work. (BA3)

BA3 mentioned that some people were there simply to comply:

I think it is because they were the sort of people who did what the Bishop said, because that's what you do, but you don't go any further. You are there and that's it, so...Any question of looking more deeply at what might be going on, and what internal drivers there might be, or of helping others to explore where they might be, that wasn't what they wanted. So, they tended to be full of bullshit! (BA3)

The importance of this being a voluntary activity is highlighted.

\section{Subordinate theme 8: poor facilitation}

BA3 mentioned the need to have good facilitation:

If you can't find the money to facilitate well, that's not going to be helpful. If you don't have a

facilitator,youruntheriskofitbecomingacollusive,ormoan, shop, butthatdoesn't meanit's not a good idea; it just means that it's not a panacea and it's got to be very carefully constructed and reviewed really...When you've got the right facilitator, that can be identified, looked at, challenged, but if there is nobody there to make those connections, and those connections are not made, then they haven't learned very much, have they really?...except that they hate groups. (BA3)

Good external facilitation seems important in keeping the group engaged in process.

\section{Subordinate theme 9: not for everyone}

BA3 felt that it was important to recognise that RGs were not for everyone:

We set up a group for new incumbents because they were a group of people with stuff in common and often feel isolated and without support. It was a good idea to have a group. It wasn't compulsory. It was just there an invitation, and one chap came and talked to me about this, and was incandescent with rage that he should be expected to waste time doing this when life was so busy. Why would he need a group? He already - he'd been 
dealing with stuff for a long time, so there was nothing he needed to know about things. I said, "I don't think it's that sort of group. I don't think it's to do with getting to know XXX. I think it's to do with them supporting each other and reflecting on practice". "Well, I can't be bothered with that sort of rubbish..." and there are always going to be people like that, and they are often the ones that undermine the efficacy of the group. So, in a sense, it would be good to find something else for them. But on the other hand, they may just learn something but one doesn't want them to wreck it for everybody else. I think you need a mixed economy. I think so much depends on really good facilitators and the right combination of people. (BA3)

\section{Subordinate theme 10: struggles with expectation}

BA6 felt that part of the cultural struggle of participation involved the difference in expectation required of group participants:

It gets caught up in a bigger picture of authority. It seems to me to be something about the nature of the Church, that whenever they think the kind of "Bishop Daddy" wants you to do it, it becomes, "Oh ah THEY are making me", or "THEY think I should do this". Or, if you are an ordinand, it is likely to be, "IF I don't do this, THEY won't ordain me." (BA6)

There can sometimes be a clash of values espoused within the body-politic of the CofE which can prevent clergy from being able to engage with vulnerability.

\section{Stage two findings}

The statistical data from the RGs' participants are presented in Table 2 . The qualitative data from the RG participants (see Table 3) highlighted hindrance factors as: dual boundaries; the commitment of others in the group; the sometimes unhelpful/helpful structure/non-structure of the sessions; where a participant is in themselves; how the group "fits" with other support structures that a participant has around them; and wanting prayer and blessing which may be perceived as manipulative. The cost was prohibitive for one participant. 
Table 2. Collated statistical data from the online surveys of diocese 1,2 and 3.

\begin{tabular}{|c|c|c|c|c|c|c|c|c|c|c|c|c|c|}
\hline \multirow[b]{3}{*}{ No. } & \multirow{3}{*}{$\begin{array}{l}\text { Statement: I have found } \\
\text { that my involvement with } \\
\text { my Reflective Practice } \\
\text { Group has been held back } \\
\text { by: }\end{array}$} & \multirow{2}{*}{\multicolumn{2}{|c|}{$\begin{array}{l}\text { Dioces } \\
\text { e 1 } \\
\text { Agree }\end{array}$}} & \multirow{2}{*}{\multicolumn{2}{|c|}{$\begin{array}{l}\text { Dioces } \\
\quad \mathrm{e} 1 \\
\text { Disagre } \\
\mathrm{e}\end{array}$}} & \multirow{2}{*}{\multicolumn{2}{|c|}{$\begin{array}{l}\text { Dioces } \\
\text { e } 2 \\
\text { Agree }\end{array}$}} & \multirow{2}{*}{\multicolumn{2}{|c|}{$\begin{array}{l}\text { Dioces } \\
\text { e } 2 \\
\text { Disagre }\end{array}$}} & \multirow{2}{*}{\multicolumn{2}{|c|}{$\begin{array}{l}\text { Dioces } \\
\text { e } 3 \\
\text { Agree }\end{array}$}} & \multicolumn{2}{|c|}{$\begin{array}{l}\text { Dioces } \\
\text { e } 3\end{array}$} \\
\hline & & & & & & & & & & & & $\begin{array}{l}\text { Disa } \\
\text { ee }\end{array}$ & \\
\hline & & $\%$ & $\begin{array}{l}\mathrm{n} \\
=\end{array}$ & $\%$ & $\begin{array}{l}\mathrm{n} \\
=\end{array}$ & $\%$ & $\begin{array}{l}\mathrm{n} \\
=\end{array}$ & $\%$ & $\begin{array}{l}\mathrm{n} \\
=\end{array}$ & $\%$ & $\begin{array}{l}\mathrm{n} \\
=\end{array}$ & $\%$ & $\begin{array}{l}\mathrm{n} \\
=\end{array}$ \\
\hline 1. & $\begin{array}{l}\text { My difficulty in committing } \\
\text { the time to attend } \\
\text { regularly }\end{array}$ & $\begin{array}{l}12 . \\
5\end{array}$ & 2 & $\begin{array}{l}87 . \\
5\end{array}$ & 14 & 0 & 0 & $\begin{array}{l}10 \\
0\end{array}$ & 7 & 7.1 & 1 & $\begin{array}{l}92 . \\
9\end{array}$ & $\begin{array}{l}1 \\
3\end{array}$ \\
\hline 2. & $\begin{array}{l}\text { My difficulty in sharing } \\
\text { openly with others }\end{array}$ & $\begin{array}{l}12 . \\
5\end{array}$ & 2 & $\begin{array}{l}87 . \\
5\end{array}$ & 14 & $\begin{array}{l}14 . \\
3\end{array}$ & 1 & $\begin{array}{l}85 . \\
7\end{array}$ & 6 & 0 & 0 & $\begin{array}{l}10 \\
0\end{array}$ & $\begin{array}{l}1 \\
4\end{array}$ \\
\hline 3. & $\begin{array}{l}\text { My difficulty in making } \\
\text { time to prioritise } \\
\text { attendance }\end{array}$ & $\begin{array}{l}12 . \\
5\end{array}$ & 2 & $\begin{array}{l}87 . \\
5\end{array}$ & 14 & 0 & 0 & $\begin{array}{l}10 \\
0\end{array}$ & 7 & 7.1 & 1 & $\begin{array}{l}92 . \\
9\end{array}$ & $\begin{array}{l}1 \\
3\end{array}$ \\
\hline 4. & Others in the group & 0 & 0 & $\begin{array}{l}10 \\
0\end{array}$ & 16 & $\begin{array}{l}28 . \\
6\end{array}$ & 2 & $\begin{array}{l}71 . \\
4\end{array}$ & 5 & 7.1 & 1 & $\begin{array}{l}92 . \\
9\end{array}$ & $\begin{array}{l}1 \\
3\end{array}$ \\
\hline 5. & The manner of facilitation & $\begin{array}{l}12 . \\
5\end{array}$ & 2 & $\begin{array}{l}87 . \\
5\end{array}$ & 14 & 0 & 0 & $\begin{array}{l}10 \\
0\end{array}$ & 7 & 0 & 0 & $\begin{array}{l}10 \\
0\end{array}$ & $\begin{array}{l}1 \\
4\end{array}$ \\
\hline 6. & $\begin{array}{l}\text { The structured nature of } \\
\text { the sessions }\end{array}$ & 6.7 & 1 & $\begin{array}{l}93 . \\
3\end{array}$ & 14 & 0 & 0 & $\begin{array}{l}10 \\
0\end{array}$ & 7 & 0 & 0 & $\begin{array}{l}10 \\
0\end{array}$ & $\begin{array}{l}1 \\
4\end{array}$ \\
\hline 7. & $\begin{array}{l}\text { The unstructured nature of } \\
\text { the sessions }\end{array}$ & 6.7 & 1 & $\begin{array}{l}93 . \\
3\end{array}$ & 14 & 0 & 0 & $\begin{array}{l}10 \\
0\end{array}$ & 7 & 0 & 0 & $\begin{array}{l}10 \\
0\end{array}$ & $\begin{array}{l}1 \\
4\end{array}$ \\
\hline 8. & The cost & 0 & 0 & $\begin{array}{l}10 \\
0\end{array}$ & 16 & 0 & 0 & $\begin{array}{l}10 \\
0\end{array}$ & 7 & 0 & 0 & $\begin{array}{l}10 \\
0\end{array}$ & $\begin{array}{l}1 \\
3\end{array}$ \\
\hline 9. & Feeling unsafe & 0 & 0 & $\begin{array}{l}10 \\
0\end{array}$ & 15 & 0 & 0 & $\begin{array}{l}10 \\
0\end{array}$ & 7 & 0 & 0 & $\begin{array}{l}10 \\
0\end{array}$ & $\begin{array}{l}1 \\
4\end{array}$ \\
\hline
\end{tabular}

Table 3. Participants' qualitative perspectives on the hindrance factors of RGs

\begin{tabular}{|l|l|}
\hline Response & $\begin{array}{l}\text { Cod } \\
\text { e }\end{array}$ \\
\hline $\begin{array}{l}\text { There is a conflict between the group and the diocesan } \\
\text { structures. While it may work for those with only local roles, } \\
\text { there can be a challenge where some have roles (themselves or } \\
\text { within their families) across the diocese, which may intersect } \\
\text { with the local roles. }\end{array}$ & D1P7 \\
\hline $\begin{array}{l}\text { With regards to the structure, I have experienced two groups } \\
\text { and the one in which there was a clearer structure of sharing, } \\
\text { listening, contributing questions in turn was more beneficial. }\end{array}$ & D1P1 \\
$\begin{array}{l}\text { The facilitator in this group was simply that - and helped us to } \\
\text { explore our own responses instead of offering too many } \\
\text { responses of her own. }\end{array}$ & \\
\hline None. It is one of my priorities. & D1P3 \\
\hline $\begin{array}{l}\text { I have been very 'talked out' at times, as I was also receiving } \\
\text { Spiritual Direction as well as individual counselling for managing } \\
\text { depression. }\end{array}$ & D1P6 \\
\hline $\begin{array}{l}\text { Sometimes it has felt a bit awkward knowing the others' } \\
\text { spouses and remembering what was said where. Sometimes } \\
\text { people wanting to 'pray' or asking for a blessing which feels } \\
\text { manipulative rather than positive. }\end{array}$ & D2P2 \\
\hline \begin{tabular}{l} 
Commitment of others in the group. \\
\hline How I am on the day.
\end{tabular} & D3P5 \\
\hline
\end{tabular}


The cost.

D3P8 


\section{Discussion}

The hindrance factors to RGs were stated by the BAs as:

- the inability of clergy to prioritise and commit to the time;

- it was scary for participants to open up to their vulnerability with others;

- sometimes the needs of some of the participants were too big, and could sabotage the group;

- dual relationships with other group participants could cause complexity and hinder sharing;

- prayer;

- being sent by a Bishop or Archdeacon;

- the open agenda and style of facilitation does not suit some people;

- sometimes there are struggles with expectations because the RG is culturally different from other groups found in the CofE;

- and geographically, the distance of the RG was prohibitive for some, although having to travel provided another reflective space for others.

However, these limitations were not the lived experience of the RG participants (albeit they are self-selected participants who may have been predisposed not to have some of these problems), with only: $12.5 \%$ (D1), $0 \%$ (D2) and $7.1 \%$ (D3) finding it difficult to commit to the time; $12.5 \%$ (D1), $14.3 \%$ (D2) and $0 \%$ (D3) struggling to share openly with others; $0 \%$ (D1), $28.6 \%$ (D2) and $7.1 \%$ (D3) struggling with others in the group; $12.5 \%$ (D1) and $0 \%$ (D2 and D3) struggling with the style of facilitation; and with 0\% (D1, D2 and D3) feeling unsafe. Other hindering factors expressed in the qualitative data from the RG participants included other external factors that were "around" for participants (e.g., D1P6 expressed feeling over-supported because of the counselling and spiritual direction that $\mathrm{s} /$ he was also having), and the difficulties with dual boundaries (D1P7, D2P2).

Whilst the concerns and experiences of the BAs are important things to be mindful of, and echo to some extent, Miles and Proeschold-Bell's (2013) research, the overwhelming evidence from the RG participants in this research is that RGs are more beneficial than not (i.e., the limitations were minimal for the RG participants). Their experience of how beneficial RGs are, is also echoed in other research (e.g., Barrett, 2010; Gubi, 2016a, 2016b; Gubi \& Korris, 2015; Travis, 2008), with the limitations something to be mindful of, but not prohibitive. Interestingly, given the context of the RGs (i.e., for clergy), prayer was considered by some (e.g., BA5, BA4 and BA8) to potentially hinder the group process or to spiritualise away the difficulties faced within the group. The lack of prayer also enabled the group to be established as "different" from other clergy groups and meetings (e.g., chapter meetings), which usually begin and end with prayer. Whilst these possibilities are things to be mindful of (Gubi, 2009), arguably the literature (e.g., Gubi, 2008) suggests that prayer can also add to a person's sense of wellbeing, and given that Chandler's(2009) research identifies "spiritual dryness" as a primary predictor of emotional exhaustion in clergy, prohibiting prayer seems counter-intuitive to the purpose of the group in promoting clergy wellbeing. However, one of the RG participants identified prayer as a hindrance to the group: “...sometimes people wanting to 'pray', or asking for a blessing, which feels manipulative rather than positive..."(D2P2). So, 
it seems that mindfulness to these tensions is important, without losing sight of the importance of the spiritual.

\section{Limitations}

Although based on a small number of participants across only three dioceses, these results indicate the perceived limitations of RGs to most participants who responded to the survey. However, this cannot be made as a universal claim of their overall hindrance factors, as the research is limited to the perceptions of eight Bishops' Advisors who arguably have an interest in validating the groups as they either organise or facilitate them, and the research is also limited to the participants from only three CofE dioceses, who presumably gained from participating in the RG experience so as to complete the evaluation. However, the data do reflect the views of 37 RG participants, and eight Bishops' Advisors, so cannot be simply dismissed as biased or trivial. This research is inevitably limited by the parameters of the research. It has been set within the context of the CofE. This provided a finite number of Bishops' Advisors to interview, but it may be the case that RGs happen in other denominations - although there is little suggestion of this in the literature. The research is limited by concentrating on members of the Anglican Association for Advisors in Pastoral Care and Counselling. This set a workable parameter for the research. The research is also limited by the response rate of the Bishops' Advisors (19\%), which meant that only eight Bishops' Advisors could be interviewed. However, the research arguably engages a sufficiently representative sample of the people who organise and/or facilitate RGs, and their views have been statistically substantiated through the surveys of 37 participants of RGs. This has enabled the research to gain a picture of established practice in supporting clergy in ministry through the use of RGs, and some of the limitations of RGs for clergy are evident from this small-scale study.

\section{Conclusion}

Whilst RGs are not the panacea for providing clergy support, this research demonstrates that many participants are able to negotiate the potential limitations and hindrances to gain benefit from participation in them (Gubi, 2016 b). It seems that careful planning to avoid dual boundaries is imperative, as is the provision of good external facilitation. This will cost financially. Voluntary participation is essential, as this enhances commitment and minimises sabotage of the process. Those who struggle relationally, or whose psychological damage may be exacerbated by the experience, arguably may need a different form of support (e.g., personal counselling). Attendance at RGs should not be expected, but encouraged. Given the perceived benefits of RGs (Barrett, 2010; Gubi, 2016b; Gubi \& Korris, 2015; Travis, 2008), the limitations should not be seen as prohibitive for everyone, but something to hold in mind when assessing the provision of such support.

\section{References}


Anglican Association of Advisors in Pastoral Care and Counselling. (2015). Retrieved from http:// pastoralcare.org.uk/contact/local-advisors-phone/

Barrett,J. (2010). Living the practice: A research inquiry into clergy use of Reflective Practice Groups in the Exeter Diocese of the Church of England (Unpublished MA dissertation). University of Middlesex.

Benson, J. R. (1987). Working more creatively in groups. London: Routledge.

Braudaway-Bauman, C. (2012). Peer power: The promise of clergy support groups. Christian Century, 11, $22-25$.

Braun, V., Clarke,V., \& Rance, N. (2015). How to use thematic analysis with interview data. In A. Vossler \& N. Moller (Eds.), The counselling and psychotherapy research handbook (pp. 183-197). London: Sage.

Chandler, D. J. (2009). Pastoral burnout and the impact of personal spiritual renewal, rest-taking, and support system practices. Journal of Pastoral Psychology, 58, 273-287. doi:10.1007/s11089-0080184-4

Francis, L. J., Robbins, M., \& Wulff, K. (2013). Assessing the effectiveness of support strategies in reducing professional burnout among clergy serving in the Presbyterian Church (USA). Practical Theology, 6(3), 319-331.

doi:10.1179/1756073X13Z.00000000021

Gubi, P. M. (2008). Prayer in counselling and psychotherapy: Exploring a hidden, meaningful dimension. London: Jessica Kingsley.

Gubi, P. M. (2009). A qualitative exploration into how the use of prayer in counselling and psychotherapy might be ethically problematic. Counselling and Psychotherapy Research, 9(2), 114-120.

Gubi, P. M. (2011). An exploration of the impact of small Spiritually Reflexive Groups on personal and spiritual development. Practical Theology Journal, 4(1), 49-66. doi:10.1558/prth.v4i1.49

Gubi, P. M. (2016a). Exploring the value of (Spiritually) Reflexive Groups in the training of ordinands and in supporting ordained persons in ministry (Unpublished ThD thesis). University of Winchester, UK.

Gubi, P. M. (2016b). Assessing the perceived value of reflexive groups for supporting clergy in the Church of England. Mental Health, Religion \& Culture. doi:10.1080/13674676.2016.1197194

Gubi, P. M., \& Korris, J. (2015). Supporting Church of England Clergy through the provision of Reflective Practice Groups. Thresholds: The Journal of BACP Spirituality Division, Winter,20 -24.

Lennie, C. (2007). The role of Personal Development Groups in counsellor training: Understanding factors contributing to self-awareness in the Personal Development Group. British Journal of Guidance and Counselling, 35(1), 115-129. doi:10.1080/03069880601106849

Lieberman, M. A. (1981). Comparative analysis of change mechanisms in groups. In H. H. Blumberg, A. P. Hare, V. Kent, \& M. Davies (Eds.), Small groups and social interaction (pp.239-252). London: Wiley. 
Miles, A., \& Proeschold-Bell, R. J. (2013). Overcoming the challenges of pastoral work? Peer Support Groups and psychological distress among United Methodist Church Clergy. Sociology of Religion, 74(2), 199-226. doi:10.1093/socrel/srs055

Moon, J. (2004). A handbook of reflective and experiential learning: Theory and practice. London: Routledge.

Robson, M., \& Robson, J. (2009). Explorations of participants' experiences of a Personal Development Group held as part of a counselling psychology training group: Is it safe here? Counselling Psychology Quarterly, 21(4), 371-382.

doi:10.1080/09515070802602153

Travis, M. (2008). Supporting clergy in postmodern ministry. Practical Theology Journal, 1(1), 95-130. doi:10.1558/prth.v1i1.95

Williams, D. I., \& Irving, J. A. (1996). Personal growth: Rogerian paradoxes. British Journal of Guidance and Counselling, 24(2), 165-172.

doi:10.1080/03069889608260406 